\title{
EKSISTENSI PEMERINTAHAN DESA DITINJAU DARI PERSPEKTIF ASAS SUBSIDIARITAS DALAM UNDANG-UNDANG NOMOR 6 TAHUN 2014 TENTANG DESA
}

\author{
Achmad Hariri \\ Fakultas Hukum Universitas Muhammadiyah Surabaya \\ Jl. Sutorejo No. 59 Surabaya \\ E-mail : achmadhariri@fh.um-surabaya.ac.id
}

\begin{abstract}
The existence of the Village Government in the perspective of Law Number 6 of 2014 concerning Villages is increasingly clear, it's because the village is given the authority to manage and regulate its own household as known as the subsidiarity principle, while independence in managing governance in regional government is known as the principle of decentralization. This authority is given to realize the vision of the life of a prosperous and independent village government. But in the implementing regulations contrary to the concepts and principles of the establishment of the Village Law, there are several norms explicitly that village authority is still intervened by the government Supra Desa (Regional Government). The purpose of this study is to analyze the existence of village government. The results of this study recommend that there is a need for synchronization and harmonization between the regulations governing village authority, namely Law number. 6 of 2014 concerning Villages, Government Regulation Number 43 of 2014 concerning Implementation Regulations of Law Number 6 Year 2014 concerning Villages, and Government Regulation Number 60 of 2014 concerning Village Funds sourced from the State Budget.
\end{abstract}

Keywords : Village Existence, Village Subsidiarity Principle, Law Number 6 of 2014 Concerning Villages

\begin{abstract}
Abstrak
Eksistensi Pemerintahan Desa dalam perspektif Undang-Undang Nomor 6 Tahun 2014 tentang Desa semakin jelas, hal ini dikarenakan desa diberikan kewenangan untuk mengelola dan mengatur rumah tangganya sendiri yang dikenalan dengan asas subsidiaritas, sedangkan kemandirian dalam mengelola pemerintahan dalam pemerintahan daerah dikenal dengan asas desentralisasi. Kewenangan tersebut diberikan untuk mewujudkan visi kehidupan pemerintahan desa sejahtera dan mandiri. Namun dalam peraturan pelaksananya bertentangan dengan konsep dan asas dibentuknya Undang-Undang tentang Desa tersebut, ada beberapa norma secara eksplisit berbunyi bahwa kewenangan desa masih diintervensi oleh pemerintah Supra Desa (Pemerintah Daerah). Penelitian ini bertujuan untuk menganalisis eksistensi pemerintahan desa pasca adanya undang-undang tentang desa. Hasil kajian ini merekomendasikan bahwa perlu adanya sinkronisasi dan harmonisasi antara peraturan yang mengatur tentang kewenangan desa, yaitu Undang-undang no. 6 tahun 2014 tentang Desa dengan peraturan pelaksananya yaitu Peraturan Pemerintah Nomor 43 Tahun 2014 Tentang Peraturan Pelaksanaan Undang-Undang Nomor 6 Tahun 2014 Tentang Desa, dan Peraturan
\end{abstract}


Pemerintah Nomor 60 tahun 2014 tentang Dana Desa yang Bersumber dari Anggaran Pendapatan dan Belanja Negara.

\section{Kata Kunci: Eksistensi Desa, Asas Subsidiaritas Desa, Undang-Undang No. 6 Tahun 2014 tentang Desa}

\section{A. PENDAHULUAN}

Desa merupakan entitas pemerintahan terendah dalam konteks Negara Kesatuan Republik Indonesia (NKRI), hal ini dapat dilihat dalam pasal 18B ayat 2 Undang-undang Dasar 1945 bahwa Negara mengakui kekhususan kesatuan-kesatuan masyarakat hukum adat yang tidak bertentangan dengan prinsip Negara Kesatuan Republik Indonesia. Dengan kata lain Negara mengakui eksistensi Desa sebagai bagian dari bentuk hirarki pemerintahan. Pasal 1 (1) Undang-Undang No. 6 tahun 2014 tentang Desa pengertian desa adalah;

Desa adalah desa dan desa adat atau yang disebut dengan nama lain, selanjutnya disebut Desa, adalah kesatuan masyarakat hukum yang memiliki batas wilayah yang berwenang untuk mengatur dan mengurus urusan pemerintahan, kepentingan masyarakat setempat berdasarkan prakarsa masyarakat, hak asal usul, dan/atau hak tradisional yang diakui dan dihormati dalam sistem pemerintahan Negara Kesatuan Republik Indonesia.

Sedangkan kewenangan pemerintah desa dapat dilihat pada Pasal 18 dan Pasal 19 Undang-udang No. 6 Tahun 2014 tentang Desa. Pasal 18 Undang-undang No.6 Tahun 2014 berbunyi "Kewenangan desa meliputi kewenangan di bidang penyelenggaraan pemerintahan desa, pelaksanaan pembangunan desa, pembinaan kemasyarakatan desa, dan pemberdayaan masyarakat desa berdasarkan prakarsa masyarakat, hak asal usul, dan adat istiadat desa". Sedangkan Pasal 19 Undang-undang No.6 Tahun 2014 berbunyi:

Kewenangan desa meliputi: a. kewenangan berdasarkan hak asal usul; b. kewenangan lokal berskala desa; c. kewenangan yang ditugaskan oleh pemerintah, pemerintah daerah provinsi, atau pemerintah daerah kabupaten/kota; dan d. kewenangan lain yang ditugaskan oleh pemerintah, pemerintah daerah provinsi, atau pemerintah daerah kabupaten/kota sesuai dengan ketentuan peraturan perundang-undangan.

Melihat dari aspek kewenangan pemerintah desa diatas, bisa dikatakan bahwa desa memiliki legitimasi dalam mengelola pemerintahan desa. Dengan kewenangan yang relatif luas yaitu desa dapat melakukan pembangnan skala desa merupakan bentuk pengakuan yang terang oleh negara terhadap pemerintah desa, dimana sebelumnya pemerintah desa masih menjadi subordinat pemerintahan supra desa seperti dalam UU No. 22 Tahun 1999 tentang Pemerintahan Daerah, dalam Undang-undang ini diatur bahwa desa merupakan bagian dari pengaturan pemerintahan daerah, dengan demikian desa menjadi daerah subsistem atau suberdinat dari pemerintahan dan pengaturannya tentang desa diserahkan pada daerah kabupaten masing-masing dengan membentuk perda sesuai dengan kebutuhan daerah. Bigitu juga dalam UU No. 32 tahun 2004 tentang pemerintahan daerah, dalam undang-undang ini desa diatur menurut undang-undang tentang pemerintahan daerah serta keberadaan pemerintahan desa berada dalam pemerintahan daerah. Asas pemerintahan desa dalam UU 
6/2014 tentang Desa salah satunya adalah asas subsidiaritas, adapun pengertian asas subsidiaritas dalam undang-undang tentang desa adalah "penetapan kewenangan berskala lokal dan pengambilan keputusan skala lokal desa".

Terkait asas subsidiaritas yang dimiliki oleh pemerintah desa tidak terlepas dengan asas desentralisasi, dimana inti dari kedua asas tersebut adalah distribution of power (pemancaran kekuasaan).Asas desentralisasi dalam konteks Negara kesatuan Romli dalam Didik G Suharto $^{1}$ menbedakan desentralisasi antara perspektif administrasi dan perspektif politik. Adapun perspektif desentralisasi politik adalah bertumpu atau berorientasi pada tujuan utama dari desentralisasi yaitu untuk mewujudkan demokrasi ditingkat lokal serta meningkatkat kesejahteraan rakyat. Sedangkan perspektif desentralisasi administratif berorientasi pada efesiensi penyelenggaraan pemerintahan daerah dan pengelolaan pembangunan skala daerah. Berangkat dari pengertian diatas, maka kedua tujuan/perspektif desentralisasi harus berjalan beriringan, jangan sampai ada disparitas, jika pemerintahan hanya lebih mengedepankan nilai demokratis, disinyalir akan mengabaikan aspek efektifitas dan efisiensi, begitu pula sebaliknya.

Menjadi menarik ketika dikaitkan antara asas desentralisasi dengan asas subsidiaritas undang-undang tentang desa, apakah kewenangan desa merupakan salah satu wujud dari desentralisasi yang kemudian akan diikuti oleh kewenangan otonomi. Untuk itu dapat dilihat dari terbentuknya undang-undang tentang desa. Adapun tujuan dari terbentuknya UU No 6 Tahun 2014 tentang Desa ini seperti temuat dalam konsideran adalah;

1. bahwa desa memiliki hak asal usul dan hak tradisional dalam mengatur dan mengurus kepentingan masyarakat setempat dan berperan mewujudkan cita-cita kemerdekaan berdasarkan Undang-Undang Dasar Negara Republik Indonesia Tahun 1945

2. bahwa dalam perjalanan ketatanegaraan Republik Indonesia, Desa telah berkembang dalam berbagai bentuk sehingga perlu dilindungi dan diberdayakan agar menjadi kuat, maju, mandiri, dan demokratis sehingga dapat menciptakan landasan yang kuat dalam melaksanakan pemerintahan dan pembangunan menuju masyarakat yang adil, makmur, dan sejahtera; dan

3. bahwa desa dalam susunan dan tata cara penyelenggaraan pemerintahan dan pembangunan perlu diatur tersendiri dengan undang-undang.

Terkait dengan asas subsidiaritas, ada kontra norma dengan beberapa pasal dalam Peraturan Pemerintah Nomor 60 tahun 2014 tentang Dana Desa yang Bersumber dari Anggaran Pendapatan dan Belanja Negara, dalam Pasal 7 ayat 1 misalnya berbunyi bahwa Pengelolaan dana desa dalam APBD kabupaten/kota dilaksanakan sesuai dengan ketentuan peraturan perundang-undangan dibidang pengelolaan keuangan daerah. Selain itu dalam Pasal 22 Ayat 3 berbunyi bahwa bupati/walikota dapat membuat pedoman teknis kegiatan yang didanai dari dana desa sesuai dengan pedoman umum kegiatan sebagaimana. Peraturan

\footnotetext{
${ }^{1}$ Didik G. Suharto, Membangun Kemandirian Desa, Pustaka Pelajar, Yogyakarta: 2016, hlm. 38.
} 
pelaksana UU tentang desa akan mencederai asas Subsidiaritas dikarenakan adanya Intervensi dan dominasi pemerintah supra desa (pemerintah daerah) sangat detemenan, sehingga desa akan menjadi ketergantungan pada pemerintah supra desa dan asas subsidiaritas tidak lagi implementatif hingga pada akhirnya cita-cita untuk mewujudkan desa yang mandiri serta demokrasi tingkat desa akan menemui kesulitan.

Berbicara soal politik pemerintahan desa hal diatas bukanlah suatu yang baru, bahwa Pemerintah pusat terlalu mengintervensi pengaturan sistem pemerintahan desa secara top down, ${ }^{2}$ dinamika politik pemerintahan desa seperti diatas juga dapat dilahat saat berlakunya Undang-Undang No. 5 tahun 1979 tentang Pemerintahan Desa. Betapa desa diseragamkan dan memformalkan desa sebagai objek pembangunan yang bercorak modernisasi. Sehingga desa kehilangan karakteristiknya dan kekhasannya. Hal ini bertentangan dengan amanat UUD 1945 yang mana masyarakat adat, desa dan lainnya dilindungai eksistensinya. Implikasinya keragaman pemerintahan desa yang ada hilang atau disegamkan inilah yang kemudian disebut unifikasi pemerintahan desa.

Berdasarkan permasalahan tersebut di atas terkait dengan eksistensi pemerintah desa ditinjau dari perspektif asas subsidiaritas dalam Undang-Undang no. 6 Tahun 2014 tentang Desa, maka kajian ini ditujukan untuk mengidentifikasi dan mengkaji eksistensi pemerintahan desa pasca pemberlakuan Undang-undang Nomor 6 tahun 2014 tentang Desa, Peraturan Pemerintah Nomor 43 Tahun 2014 Tentang Peraturan Pelaksanaan Undang-Undang Nomor 6 Tahun 2014 Tentang Desa, dan Peraturan Pemerintah Nomor 60 tahun 2014 tentang Dana Desa yang Bersumber dari Anggaran Pendapatan dan Belanja Negara, sehingga desa memiliki peran yang besar dalam mewujudkan kesejahteraan masyarakat desa sesuai dengan asas subsidiaritas.

\section{B. PEMBAHASAN}

\section{Sejarah Pemerintahan Desa}

Sejarah pemerintah desa di Indonesia dapat dilihat dari perjalanan pemerintahan desa jauh sebelum terbentuknya Negara Republik Indonesia, penamaan pemerintah desa berbeda-beda disetiap daerah, ada Nagari, Marga, Gampong, Meusanah, Huta, Negorij, dan sebagainya, ini menandakan Bahwa desa di Indonesia majemuk baik dalam penamaan maupun dalam sistem pemerintahannya. Pemerintah desa pada zaman prakolonial (sebelum datanya penjajahan), kolonial, pasca kemerdekaan, orde lama, orde baru hingga era reformasi ditempatkan dalam subordinat dari pemerintah supra desa. ${ }^{3}$ Padahal kedudukan dan kewenangan desa dalam sejarah desa diposisikan sebagai desa otonom yaitu mempunyai pemerintahan sendiri (self-governing community) dengan menggunakan hukum adat. Tetapi setelah negara, yang dimulai dari masa kolonial, maka kepemilikan pemerintahan dan sumber daya alam diambil alih oleh negara. ${ }^{4}$ Ateng

\footnotetext{
${ }^{2}$ Didik, Op.Cit, hlm. 7.

${ }^{3}$ Didik, Ibid, hlm. 10

${ }^{4}$ Didik, Op.Cit, hlm. 17.
} 
Syafrudin dan Suprin Na'a dalam Solekha ${ }^{5}$ memberikan penjelasan; Pertama, C. Van Vollenhoven dalam bukunya Staatrecht Overzee, pemerintah republik desa eksistensinya mendahului masuknya kolonialisasi oleh Belanda masuk ke Indonesia. Kedua, disaat pemerintahan kolonial Belanda masuk dan menjajah Indonesia pemeritahan desa diberikan keleluasaan untuk mengatur pemerintah sendiri berdasarkan hukum adat masing masing desa, hal tersebut dapat dilihat dalam pasal 128 ayat (3) indische staatsregeling (IS) tanggal 2 september 1854, staadblad tahun 1854 No. $2{ }^{6}$

Secara eksplisit pasal 18 Undang-Undang Dasar 1945 membagi desa menjadi dua yaitu desa administratif yang memiliki fungsi pembantuan dari pemerintah diatasnya, dan desa adat yang memiliki fungsi otonomi dalam melaksanakan pemerintahannya. Eksistensi dan perkembangan otonomi asli desa bukan penyerahan dari pemerintah supra desa, otonomi asli tersebut tumbuh dan berkembang dengan arifan yang ada pada desa. ${ }^{7}$ Secara konstitusi desa memiliki kewenangan otonom dalam mengelola pemerintahannya, sejalan dengan itu Joesef Mario, ${ }^{8}$ membagi desa menjadi empat tipe; pertama, Desa Adat adalah Desa asli dan eksistensi lebebihi atau lebih dulu ada dari keberadaan Negara Indonesia, desa adat ini kemudian dikenal denga istilah otonomi asli. Kedua, Desa administratif adalah desa dengan satuan pemerintahan terentah untuk memberikan pelayanan administrasi dari pemerintah pusat. Ketiga, desa otonom adalah desa dengan dasar asas desentralisasi yang diberikan oleh pemerintah pusat dalam konteks negara kesatuan. Keempat, desa campuran adalah desa campuran antara desa adat dan semi otonom, karakteristik desa campuran ini adalah desa yang memiliki kewenangan antara otonomi asli dan semi otonomi formal.

Menurut Soepomo Negara Republik Indonesia mendasari atas republik desa", dimana desa merupakan unsur terpentin dalam negara Indonesia, republik desa juga memiliki cita negara, hal ini menjadi justiikasi bahwa hadirnya negara Indonesia memiliki kesamaan hakikat dengan begitu dapat dikatakan bahwa republik desa merupakan embrio lahirnya negara. Mengenai embrio negara republik Indonesia terdapat pada paguyuban masyarakat desa para pemimpinnya bersatu dengan rakyat dan masyarakat. ${ }^{9}$ Lebih lanjut Soepomo, pada sidang BPUPK, menyinggung konsep sekaitan dengan mekanisme pemerintahan negara ini, ia menyampaikan bahwa otonomi daerah sebagai prinsip berarti menghormati apa yang ada pada wilayah regional. Hal ini meliputi riwayat, adat ada sifatnya sendiri-sendiri, dalam kadar negara kesatuan. ${ }^{10}$ Sejarah dinamika pemerintahan desa menjadi saksi bahwa eksistensi pemerintahan desa memiliki

\footnotetext{
5 Moch. Solekhan, Penyelenggaraan Pemerintahan Desa Berbasis Partisipasi Masyarakat, Setara Press, Malang: 2014, hlm. 24.

${ }^{6}$ Nikmatul, Op.Cit, hlm. 3.

${ }^{7}$ Nikmatul, Ibid, hlm. 11.

${ }^{8}$ Josef Mario Monteiro, Hukum Pemerintahan Daerah, Pustaka Yustisia, Yogyakarta: 2016, hlm. 123-124

${ }^{9}$ Nikmatul, Ibid, hlm. 1.

${ }^{10}$ Samsul Wahidin, Hukum Pemerintahan Daerah, Pendulum Otonomi Daerah Dari Masa Ke Masa,.Pustaka Pelajar, Yogyakarta: 2013, hlm. 29.
} 
tempat yang determinan dalam negara bahkan negara dalam konstitusinya mengakui pemerintahan desa sebagai pemerintahan adat yang otonom.

Sejarah pemerintahan desa juga dapat dilihat dari politik hukum pemerintahan desa, dalam politik hukum pemerintaha desa dapat dilihat bahwa dinamika pemerintahan desa sudah ada sejak dulu dan menjadi perhatian pemerintah pusat, pada masa orde lama pemerintah desa eksistensinya sangat jelas, hal ini dapat dilahat dalam uu nomor 19 tahun 1965 "Desa ditempatkan sebagai daerah tingkat III dengan tata dan sebuah desa praja". Namun pada rezim orde baru otonomi seluas-luasnya dicabut oleh pemerintah diganti dengan otonomi nyata dan bertanggungjawab ${ }^{12}$ yang juga berpengaruh pada pemerintah desa. Pemerintah orde baru mencabu tap MPRS No. XXI/MPRS/1966 tentang otonomi daerah dan kemudian dijabarkan dalam uu no. 5 tahun 1979 tentang otonomi daerah dalam undang-undang ini nampak dominan ke-Ika-annya daripada kebhinekaannya. Poliutik hukum pemerintahan daerah ini dikenal dengan istilah "sentralisme hukum" yang memilih keseragaman daripada kebhinekaan. ${ }^{13}$

\section{Asas Subsidiaritas dalam Negara Kesatuan}

Pembentukan Undang -undang nomor 6 tahun 2014 tentang Desa berasaskan pada tiga belas asas yaitu, rekognisi, subsidiaritas, kebersamaan, keberagaman, kegotongroyongan, kekeluargaan, demokrasi, musyawarah, kemandirian, kesetaraan, pemberdayaan, partisipasi dan keberlanjutan. Salah satu asas diatas asas Subsidiaritas, yaitu bentuk pengakuan dan penetapan kewenangan pemerintah desa dalam mengelola dapur pemerintahannya sendiri yang bertujan pada kepentingan masyarakat desa, hal ini menegaskan bahwa Desa dengan UU No 6 Tahun 2014 tentang desa ini memiliki posisioning yang otonom, desa diakui sebagai hak asal usul, seperti penjelasan sebelumnya bahwa desa sejak dulu sudah otonom, dan asas subsidioritas, kewenangan yang berskala lokal desa dalam mengatur segala aktivitas penyelenggaraanya. Asas diatas dapat ditafsirkann bahwa kewenangan desa sangat luas dan desa memiliki hak mengatur dan mengurus rumah tangganya sendiri, hal ini sejalan dengan amanat UUD 1945 pasal 18B yaitu pengakuan berdasarkan asal usul dan adat istiadat setempat (self-governing community), kewenangannya otonom tapa adaintervensi dari pemerintah supra desa. ${ }^{14}$

Dalam konteks negara republik atau negara kesatuan secara konseptual, kewenangan tersentral pada pemerintah pusat, pemerintah daerah hanya diberikan sebagian kewenangan untuk mengurusi suatu bidang tertentu yang kemudian ini dikenal dengan konsep desentralisasi. Jimly Assiddiqie, berpendapat bahwa negara kesatuan

\footnotetext{
${ }^{11}$ Didik Sukrino, Hukum, Konstitusi, dan Konsep Otonomi; Kajian Politik Hukum tentang Konstitusi Otonomi Daerah dan Desa Pasca Perubahan Konstitusi, Setara Press, Malang: 2016, hlm. 179.

${ }^{12}$ Yusnani Hasyimzoem, "Dinamikan Hukum Pemerintahan Desa", Fiat Justisia Jurnal Ilmu Hukum, No. 3, Vol. 8, 2014, hlm. 473.

${ }^{13}$ Ateng Syafrudin, Suprin Na'a, Republik Desa Pergulatan Hukum Tradisional dan Hukum Modern dalam Desain Otonomi Desa, PT. Alumni, Bandung: 2010, hlm. 21

${ }^{14}$ Didik Op.Cit, hlm. 12
} 
dimana kekuasaan negara terbagi antara pemerintah pusat dan daerah. Namun kekuasaaan asli berada pada pemerintah pusat. ${ }^{15}$ kewenangan Negara Republik kewenanagan yang besar adalah pemerintah pusat (central goverment). Sehinga ini yang mendasari bahwa dalam negara kesatuan (republik) kewenanagan daearah (desentralisasi) adalah berian dari pemerintah pusat, adapun bentuk Negara kesatuan terklasifikasikan pada dua struktur tingkatan utama, yaitu pemerintah pusat dan pemerintah daerah (provinsi, kabupaten/kotamadya. ${ }^{16}$

Dapat diartikan bahwa negara kesatuan adalah negara merdeka dan berdaulat dan pusat kukuasaannya dipegang oleh pemerintah (pusat). Esensi kedaulatan dalam negara kesatuan pelaksana tugas-tugas pemerintahan pada dasarnya berada pada pemerintah pusat. Namun dalam konteks negara Indonesia yang wilayahnya besar dan las maka dianutlah bentu negara kesatuan dengan asas desentralisasi, dengan asas desentralisasi ini menyebabkan urusan pemerintahan tertentu dapat didelegasikan pada daerah, dengan begitu delegasi urusan pemerintahan ini dapat berjalan baik kalau dilaksanakan dengan maksimal, asas desentralisasi ini menyebabkan adanya hubungan kewenangan dan pengawasan antara pemerintah pusat dan daerah. ${ }^{17}$ Aturan mengeai konsep pemerintahan daerah tertuang dalam Pasal 18B UUD 1945, diantaranya adanya desentralisasi yang akan melahirkan otonomi daerah dalam penyelenggaraan pemerintahan daerah, penyelenggaraan satuan pemerintahan daerah harus memperhatikan dasar permusyawaratan dalam sistem pemerintahan negara", satuan pemerintahan daerah diselenggarakn dengan memperhatikan hak-hak asal usul dalam daerah-daerah yang bersifat istimewa. ${ }^{18}$

Otonomi daerah itu bermakna sebagai wujud dari kewenangan untuk mengatur rumah tangga pemerintah daerah. Dari hal kewenangan, pada dasarnya otonomi daerah itu mengandung muatan kewenangan yang bersifat mandiri. ${ }^{19}$ Namun dalam konteks negara kesatuan, sebagaimana otonomi daerah yang dijelasakan dalam UU No 23 tahun 2014 merupakan otonomi berian, atau kewajiban pusat, otonomi daerah bukan merupakan hak daerah, sehingga adanya pemekaran daerah itu merupakan kewajiban pusat setelah dilakukan analisis-analisis bahwa daerah itu benar-benar perlu dilakukan pemekaran. Lain halnya dengan konsep otonomi Desa, kalau otonomi daerah itu merupakan Hak yang bersifat berian, karna wewenang adalah pemberian maka harus diawasi dan dipertanggungjawabkan kepada pemerintah pusat. Namun, pemerintah Desa memiliki otonomi sebagai hak bawaaan, otonomi ini tumbuh dan berkembang. Hak otonomi bawaaan Desa disebut susunan asli itu atas wilayah, otonomi ini dapat ditemukan dalam konteks wilayah hak ulayat, hukum adat, dan mekanisme pembuatan

15 Lukman Santoso, Hukum Pemerintahan Daerah; Mengurai Problematika Pemekaran Daerah Pasca Reformasi di Indonesia, Pustaka Pelajar, Yogyakarta: 2015, hlm. 23.

${ }^{16}$ Lukman Ibid, hlm. 26.

${ }^{17}$ Nikmatul, Op. Cit, hlm. 100-101.

${ }^{18}$ Nikmatul, Ibid, hlm. 7

${ }^{19}$ Samsul, Op.Cit, hlm. 3-4. 
aturan. ${ }^{20}$ Hal ini memperkuat eksistensi desa dalam perspektif historis, seperti penjelasan diatas, bahwa desa sudah ada sebelum adanya negara, sehingga eksistensi desa lebih dulu daripada adanya negara.

Namun berbeda pendapat didik G. Sugio, bahwa dalam konteks pemerintah Kabupaten/kota dilarang memberikan desentralisasi kepada desa, pemerintah desa hanya memiliki peran supervisi kepada dan pembinaan kepada desa, sebagaimana provinsi melakukan hal yang sama kepada kabupaten/kota. Walaupun pemerintah desa merupakan subsistem pemerintahan kabupaten/ kota, tapi tidak ada teori yang memboleh pemerintah daerah memberikan kewenangan urusan pemerintah desa. ${ }^{21}$ Relasi asas desentralisasi dengan asas subdiaritas menjadi penting untuk mewujudkan kesejahteraan desa, dengan mengelola pemerintah desa sendiri. Asas desentralisasi ini merupakan manifestasi dari demokrasi yang bertujuan terciptanya pemerintahan yang baik dan berkedaulatan rakyat. Selanjutnya agar perjalanan desentralisasi ini dapat berjalan dengan baik pemerintah pusat melakukan pengawasan, monitoring dan evaluasi terhadap daerah, hal ini dilakuakan sepanjang tidak mengebiri kewenangan yang sudah diberikan kepada daerah, hal ini sejalan dengan perluasan makna asas subsidiaritas yaitu kewenangan berskala lokal dan pengambilan keputusan secara lokal yang berada pada desa. Perluasan kewenangan itu harus menjamin terwujudnya dampak (re) distribusi ${ }^{22}$, sehingg terwujud pemerintahan desa yang partisipatoris tidak hanya tersentral ada pejabat desa.

Menurut Sutoro Eko (2015) dalam Dekki Umamur Ra'is. Mengartikan makkna subsidiaritas sebagai lokalitas penggunaan kewenangan dalam pengambilan keputusan yang menjunjung tinggi kemandirian dan dan kepentingan masyarakat desa. Subsidiaritas dibedakan dengan asas desentralisassi, makna yaitu menetapkan kewenangan lokal berskala desa menjadi kewenangan desa melalui Undang-Undang. Terakhir subsidiaritas dapat berjalan jika pemerintah tidak melakukan intervensi terhadap kewenangan lokal desa, pemerintah supra desa memiliki fingsi sebagai pengawas dan supervisi sehingga pembangunan desa dapat terarah dan maksimal, sesuai amanat undang-undang tentang desa. Kepercayaan yang besar yang diberikan oleh pemerintah supra desa yaitu berupa tanggungjawab pada pemerintah desa merupakan pondasi terwujudnya asas subsidiaritas. Tugas pemerintah supra desa adalah mendorong, memberikan kepercayaan dan mendukung prakarsa dan tindakan desa dalam mengurus kepentingan masyarakat desa. ${ }^{23}$

\section{Eksistensi Desa Setelah Berlakunya UU No 6 Tahun 2014}

Pemberian kewenangan pemerintah desa dengan asas subsidiaritas dikelola oleh kepala desa, Badan Permusyawarantan Desa (BPD) dan juga masyarakat desa. Kepala

\footnotetext{
${ }^{20}$ Nikmatul, Op.Cit, hlm. 16.

${ }^{21}$ Didik, Op. Cit, hlm. 13.

${ }^{22}$ Mohamad Sohibudin, "Peluang dan Tantangan Undang-undang Desa dalam Upaya Demokratisasi Tata Kelola Sumber Daya Alam Desa Perspektif Agraria Kritis, Masyarakat", Jurnal Sosiologi, No.1, Vol. 21, 2016, hlm. 26.

23 Dekki Umamur Ra'is, Kebijakan Pemberdayaan Masyarakat Dalam Persfektif Asas Rekognisi Dan Subsidiaritas Undang-undang desa Nomor 6 Tahun 2014” Reformasi Vol. 7 No. 12017 hlm. 36.
} 
desa dijelaskan dalam Pasal 1 ayat (1) UU No. 6 Tahun 2014 adalah bertugas menyelenggarakan pemerintahan desa, melaksanakan pembangunan desa, pembinaan kemasyarakatan desa, dan pemberdayaan masyarakat desa. Kepala desa berwenangn memimpin penyelenggaraan demerintahan desa, mengangkat dan memberhentikan perangkat desa, memegang kekuasaan pengelolaan keuangan dan aset desa, menetapkan peraturan desa, menetapkan anggaran pendapatan dan belanja desa, membina kehidupan masyarakat desa, membina ketenteraman dan ketertiban masyarakat desa, membina dan meningkatkan perekonomian desa serta mengintegrasikannya agar mencapai perekonomian skala produktif untuk sebesar-besarnya kemakmuran masyarakat desa, mengembangkan sumber pendapatan desa, mengusulkan dan menerima pelimpahan sebagian kekayaan negara guna meningkatkan kesejahteraan masyarakat desa, mengembangkan kehidupan sosial budaya masyarakat Desa, memanfaatkan teknologi tepat guna, mengoordinasikan Pembangunan Desa secara partisipatif.

Adapun Badan Permusyawaratan Desa (BPD) mempunyai fungsi: Pertama, membahas dan menyepakati Rancangan Peraturan Desa bersama Kepala Desa; Kedua, menampung dan menyalurkan aspirasi masyarakat Desa; Ketiga, melakukan pengawasan kinerja Kepala Desa. Anggota Badan Permusyawaratan Desa merupakan wakil dari penduduk Desa berdasarkan keterwakilan wilayah yang pengisiannya dilakukan secara demokratis. adapun masa keanggotaan Badan Permusyawaratan Desa selama 6 (enam) tahun terhitung sejak tanggal pengucapan sumpah/janji. Anggota Badan Permusyawaratan Desa dapat dipilih untuk masa keanggotaan paling banyak 3 (tiga) kali secara berturut-turut atau tidak secara berturut-turut. BPD merupakan manifstasi dari demokratisasi lokal desa peenyelenggaraan pemerintahan yang kuat hanya dapat terwujud jika partisipasi masyarakat lokal desa sangt tinggi dalam pembangunan desa, maka tidak berlebihan jika BPD merupakan "parlemen" nya desa karena memiliki peran sebagai pembuat dan pengesah peraturan desa, sebagai wujud dari perwakilan masyarakat lokal desa. $^{24}$

Dalam mewujudkan pemerintah desa yang maju, optimalisasi peran dan fungsi BPD sangatlah penting, ibarat bangunan BPD sebagai pilar bangunan desa, sehingga kuat dan lemahnya pemerintahan desa sedikit banyak akan bergantung pada BPD, ada beberapa peran BPD yang sangat sentral dalam pengawasan pembangunan desa, khususnya dalam pengawasan keuangan desa, antara lain, pengedalian keuangan, pengawasan keuanga, pemantauan, evaluasi dan supervisi. ${ }^{25}$ Semua itu akan dapat berjalan dengan baik apabila dibaerengi oleh partisipasi tinggi masyarakat desa. Selain itu juga fungsi BPD adalah menjadi wadah penampung aspirasi rakyat, BPD juga dapat

\footnotetext{
${ }^{24}$ Estepanus Dauwole, Johannis Kaawoan, Yurnie Sendow, "Peranan Badan Permusyawaratan Desa Dalam Perencanaan Pembangunan (Suatu Studi Di Desa Tolabit Kecamatan KaoKabupaten Halmahera Utara)", Eksekutif Jurnal Jurusan Ilmu Pemerintahan, No. 2 Vol. 2, 2017, hlm. 4.

${ }^{25}$ Darmini Roza, Laurensius Arliman S, "Peran Badan Permusyawartan Desa di dalam Pembanguna Desa dan pengawasan keuangan Desa”, PJIH, No. 3, Vol. 4, 2017, hlm. 620.
} 
memberikan teguran kepada aparatur desa yang tidak sejalan dengan pembangunan yang telah direncanakan.

Kewenangan desa berdasar pada Pasal 19 UU No. 6 Tahun 2014 meliputi: a) kewenangan berdasarkan hak asal usul; b) kewenangan lokal berskala desa; c) kewenangan yang ditugaskan oleh pemerintah, pemerintah daerah provinsi, atau pemerintah daerah Kabupaten/Kota; d) kewenangan lain yang ditugaskan oleh pemerintah, pemerintah daerah provinsi, atau pemerintah daerah kabupaten/kota sesuai dengan ketentuan peraturan perundang-undangan. Pasal 26 UU No. 6 Tahun 2014 menyebutkan; asas penyelenggaraan pemerintahan desa yaitu: kepastian hukum, tertib penyelenggaraan pemerintahan, tertib kepentingan umum, keterbukaan, proporsionalitas, profesionalitas, akuntabilitas, efektivitas dan efisiensi, kearifan lokal, keberagaman dan partisipatif.

Adanya kebijakan desentralisasi dalam konteks pemerintahan desa belum memberikan hal yang nampak, ${ }^{26}$, yaitu belum mewujudkann pemerintahan desa yang efektif dan efisien. meskipun tujuan dari adanya otonomi daerah, tidak lain yaitu untuk meningkatkan kesejahteraan rakyat di daerah. Distorsi penyelenggaraan desa nampak dalam hal pengelolaan dana desa mulai teknis penyalurannya hingga pertanggujawabannya, adanya keterlibatan kabupaten yang cukup besar hal ini yang membuat otonomi desa tersubordinat, dalam pasal 96 ayat 5 PP. No. 43 tahun 2014 tentang peraturan pelaksana UU No. 6 tahun 2014 tentang Desa "ketentuan dalam tata cara pengalokasian Alokasi Dana Desa (ADD) diatur dengan peraturan bupati/walikota". Padahal dalam pembangunan pemerintah desa dikenal dengan otonomi asli yaitu menkankan pada kemandirian desa, eksistensi pemerintahan desa tidak terikat hirarkhisstruktural sehingga desa secara otentik dapat mengatur dan mengurus pemerintahannya sendiri. $^{27}$

Dalam penjelasan pasal 72 huruf b. Peraturan Pemerintah Nomor 43 Tahun 2014 Tentang Peraturan Pelaksanaan Undang-Undang Nomor 6 Tahun 2014 Tentang Desa, yang dimaksud dengan "Anggaran bersumber dari anggaran pendapatan dan belanja negara tersebut" adalah anggaran yang diperuntukkan bagi desa dan desa adat yang ditransfer melalui anggaran pendapatan dan belanja daerah kabupaten/kota yang digunakan untuk membiayai penyelenggaraan pemerintahan, pembangunan, serta pemberdayaan masyarakat, dan kemasyarakatan. Lebih lanjut, Pasal 48 berbunyi; dalam melaksanakan tugas, kewenangan, hak, dan kewajibannya, kepala Desa wajib: a. menyampaikan laporan penyelenggaraan pemerintahan desa setiap akhir tahun anggaran kepada bupati/walikota; b. menyampaikan laporan penyelenggaraan pemerintahan desa pada akhir masa jabatan kepada bupati/walikota; c. menyampaikan laporan keterangan penyelenggaraan pemerintahan secara tertulis kepada badan permusyawaratan desa setiap

${ }^{26}$ Didik, Op.Cit. hlm. 10.

${ }^{27}$ Utang Suwaryo, “Mengembalikan Otonomi Untuk Desa”, Governance, No. 1, Vol. 2, 2011, hlm. 4. 
akhir tahun anggaran. Pasal 95 (1) pemerintah mengalokasikan dana desa dalam anggaran pendapatan dan belanja negara setiap tahun anggaran yang diperuntukkan bagi desa yang ditransfer melalui anggaran pendapatan dan belanja daerah kabupaten/kota. Secara politik pemerintahan, ketergantungan pemerintah Desa kepada pemerintah daerah akan berdampak kurang baik, selain tidak terjadinya efektifitas dan efisiensi juga berpengaruh pada program-program yang akan dijalankan oleh pemerintah desa.

Peraturan Pemerintah Nomor 60 tahun 2014 tentang Dana Desa yang Bersumber dari Anggaran Pendapatan dan Belanja Negara, Pasal 7 ayat 1 berbunyi pengelolaan dana desa dalam APBD kabupaten/kota dilaksanakan sesuai dengan ketentuan peraturan perundang-undangan dibidang pengelolaan keuangan daerah. Sedangkan dalam Pasal 22 Ayat 3 bupati/walikota dapat membuat pedoman teknis kegiatan yang didanai dari dana desa sesuai dengan pedoman umum kegiatan sebagaimana. Intervensi dan dominasi pemerintah daerah pada pemerintah desa masih sangat besar, sehingga desa akan menjadi ketergantungan pada pemerintah supra desa, sehingga cita-cita untuk mewujudkan desa yang mandiri sangat sulit terjadi. Padahal tujuan pemberian dana desa ini adalah untuk meningkatkan kesejahteraan masyarakat desa. Namun, dalam pelaksanaannya keterlibatan masyarakat dalam pembangunan desa secara aktif dalam pengelolaan dana desa belum maksimal. ${ }^{28}$

Norma wewenang Desa dalam melaksanakan rumah tangganya masih ada subordinat oleh supra Desa, kewenangan kabupaten/kota dalam mengintervensi Desa sangat besar, dan ini bersebarangan dengan semangat terbentuknya UU No. 6 tahun 2014 tentang Desa yang bercita-cita mewujudkan kemandirian Desa, yaitu Desa memiliki kewenangan untuk mengatur rumah tangganya sendiri, bukan diatur oleh supra Desa. Selain itu, hal ini bertentanngan dengan teori desentralisasi, bahwa kabupeten/kota yang merupakan daerah otonom memberikan kewenangan dekonsentrasi kepada Desa, padahal dalam teori desentralisasi dalam konteks Negara kesatuan hanya Pusatlah yang bisa memberikan dekonsentrasi kepada daerah bukan Daerah kepada Desa, idealnya Desa sama dengan kabupaten/kota, tugas kabupaten/kota hanya bertugas supervisi pada Desa. Kenyataanya otonomi desa hanya merupakan pelengkap dari otonomi daerah. ${ }^{29}$ Meskipun begitu, landasan ontologis pemerintah desa membenarkan bahwa dalam pengaturan pemerintahan desa harus memperhatikan keanekaragaman, demokratisasi, partisipatoris, otonomi asli dan pemberdayaan kepada masyarakat desa. ${ }^{30}$ Untuk memperkuat posisi desa sebagai asas subsidiaritas, desa harus diposiskan sebagai "Development Community" artinya desa bukan hanya berfungsi sebagai administrasi akan tetapi sebagai

\footnotetext{
${ }^{28}$ Nyimas Latifah Letty Aziz, “Otonomi Desa Dan Efektivitas Dana Desa”, Jurnal Penelitian Politik, No. 2, Vol. 13, 2016, hlm. 193.

${ }^{29}$ Nyimas, Ibid. hlm. 195.

${ }^{30}$ Ateng Syafrudin et al, Op.Cit, hlm. 17.
} 
"Independent Com-munity" artinya masyarakatnya berhak berbicara atas kepentingan masya-rakat lokal desa. ${ }^{31}$

Otonomi desa dengan asas subsidiaritas Desa dengan adanya intervensi pemerintahan diatasnya akan menyebabkan sedikit kurang optimal pengelolaan pemerintahan desa, karena akan menghambat terjadinya demokratisasi pemerintahan desa, yang terjadi pemerintah desa akan tergantung pada kebijakan pemerintah supra desa dalam menjalankan pemerintahan desa. UU No.6/2014 memberikan ruang gerak yang luas dalam melakukan pembangunan desa tanpa terbebani oleh program-program kerja dari pemerintah supra desa. ${ }^{32}$ Seperti halnya cita-cita negara welferstaat (negara kesejahteraan) bahwa sedapat mungkin Pengembangan otonomi Desa hendaknya diarahkan pada misi untuk menciptakan kesejahteraan rakyat. ${ }^{33}$ Seamkin dekan pelayanan itu diberikan maka akan semakin tinggi tingkat kepuasan yang diterima oleh rakyat, seperti misalnya partisipasi pembangunan yang diberikan langsung oleh masyarakat, meningkatnya peran aktif masyarakat dalam pengambilan keputusan pembangunan secara, demokratis, bertanggung jawab dan terbuka merupakan tujuan dari pengembangan potensi desa. ${ }^{34}$ Sejalan dengan Mardiasmo, (2004) bahwa Konsep otonomi desa memungkinkan kewenangan dan keleluasaan (diskresi) kepada pemerintah desa untuk mengatur dan menentukan penggunaan dana dalam melaksanakan urusanurusannya. ${ }^{35}$ Pada gilirannya implentasi dari undang-undang tentang desa tidak sesuai dengan cita-cita perundangan tersebut dibuat, yaitu untuk mewujudkan kesejahteraan masyarakat desa, tanpa diikuti dengan kebijakan supra desa yang mendukung kemajuan desa dan terwujudnya pembangunan desa maka akan sulit meweudkan desa yang maju dan mandiri.

\section{PENUTUP}

Konsistensi dalam pelakasanaan otonomi desa perlu ditekankan lagi, seperti asas subdiaritas perlu adanya peraturan yang pelaksanan yang sesuai dengan tujuan asas tersebut, yaitu pasal 7 ayat 1 dan pasal 22 ayat 3 dalam Peraturan Pemerintah Nomor 60 tahun 2014 tentang Dana Desa yang Bersumber dari Anggaran Pendapatan dan Belanja Negara. hal ini bertolak belakang dengan eksistensi pementahan desa yang memiliki otonomi asli secara historis dikenal sebagai desa adat. Sehingga pelaksanaan pemerintahan desa dapat diwujudkan sesuai dengan asas otonomi desa yaitu desa dapat mengelola pemerintahannya sendiri dalam koridor Negara Kesatuan Republik Indonesia yang mana kewenangan absolut ada pada

\footnotetext{
${ }^{31}$ Edy Supriadi, "Pertanggungjawaban Kepala Desa Dalam Pengelolaan Keuangan Desa Berdasarkan Undangundang Nomor 6 Tahun 2014 Tentang Desa”, Jurnal IuS, No. 3, Vol. 8, 2015, hlm. 344.

${ }^{32}$ Nyimas, Loc.Cit., hlm. 196.

${ }^{33}$ Sutrisno Purwohadi Mulyono, "Sinergitas Penyelenggaraan Pemerintahan Desa”, MMH, No. 3, Jilid 43, 2014, hlm. 444.

34 Antono Herry P.A, Kesiapan Desa Menghadapi Implementasi Undang-Undang Desa (Tinjauan Desentralisasi Fiskal dan Peningkatan Potensi Desa), Jurnal Ilmiah CIVIS, Volume V, No 1, 2015, hlm, 745

${ }^{35}$ Muhammad Zainul Abidin, Tinjauan Atas Pelaksanaan Keuangan Desa Dalam Mendukung Kebijakan Dana Desa, Jurnal Ekonomi \& Kebijakan Publik, Vol. 6 No. 1, 2015 hlm, 65
} 
pemerintah pusat, dengan begitu diharapkan akan terwujud pengembangan Desa yang demokratis serta pembangunan yang memang didukung oleh masyarakat desa, sehingga apa yang dicita-cita negara welfare state (negara kesejahteraan) akan terwujud di level pemerintahan paling bawah, yaitu pemerintahan desa.

\section{DAFTAR PUSTAKA}

\section{Buku}

Ateng Syafrudin, Suprin Na'a, Republik Desa Pergulatan Hukum Tradisional dan Hukum Modern dalam Desain Otonomi Desa, PT. Alumni, Bandung: 2010.

Didik G. Suharto, Membangun Kemandirian Desa, Pustaka Pelajar, Yogyakarta: 2016.

Didik Sukrino, Hukum, Konstitusi, dan Konsep Otonomi; Kajian Politik Hukum tentang Konstitusi Otonomi Daerah dan Desa Pasca Perubahan Konstitusi, Setara Press, Malang: 2016.

Josef Mario Monteiro, Hukum Pemerintahan Daerah, Pustaka Yustisia, Yogyakarta: 2016.

Lukman Santoso, Hukum Pemerintahan Daerah; Mengurai Problematika Pemekaran Daerah Pasca Reformasi di Indonesia, Pustaka Pelajar, Yogyakarta: 2015.

Moch. Solekhan, Penyelenggaraan Pemerintahan Desa Berbasis Partisipasi Masyarakat, Setara Press, Malang: 2014.

Samsul Wahidin, Hukum Pemerintahan Daerah, Pendulum Otonomi Daerah Dari Masa Ke Masa,.Pustaka Pelajar, Yogyakarta: 2013.

\section{Jurnal}

Antono Herry P.A, Kesiapan Desa Menghadapi Implementasi Undang-Undang Desa (Tinjauan Desentralisasi Fiskal dan Peningkatan Potensi Desa), Jurnal Ilmiah CIVIS, Volume V, No 1, 2015.

Darmini Roza, Laurensius Arliman S, "Peran Badan Permusyawartan Desa di dalam Pembanguna Desa dan pengawasan keuangan Desa”, PJIH, No. 3, Vol. 4, 2017.

Dekki Umamur Ra'is, Kebijakan Pemberdayaan Masyarakat Dalam Persfektif Asas Rekognisi Dan Subsidiaritas Undang-undang desa Nomor 6 Tahun 2014" Reformasi Vol. 7 No. 12017.

Edy Supriadi, "Pertanggungjawaban Kepala Desa Dalam Pengelolaan Keuangan Desa Berdasarkan Undangundang Nomor 6 Tahun 2014 Tentang Desa”, Jurnal IuS, No. 3, Vol. 8, 2015.

Estepanus Dauwole, Johannis Kaawoan, Yurnie Sendow, "Peranan Badan Permusyawaratan Desa Dalam Perencanaan Pembangunan (Suatu Studi Di Desa Tolabit Kecamatan KaoKabupaten Halmahera Utara)", Eksekutif Jurnal Jurusan Ilmu Pemerintahan, No. 2 Vol. 2, 2017. 
Mohamad Sohibudin, "Peluang dan Tantangan Undang-undang Desa dalam Upaya Demokratisasi Tata Kelola Sumber Daya Alam Desa Perspektif Agraria Kritis, Masyarakat", Jurnal Sosiologi, No.1, Vol. 21, 2016.

Muhammad Zainul Abidin, Tinjauan Atas Pelaksanaan Keuangan Desa Dalam Mendukung Kebijakan Dana Desa, Jurnal Ekonomi \& Kebijakan Publik, Vol. 6 No. 1, 2015.

Nyimas Latifah Letty Aziz, "Otonomi Desa Dan Efektivitas Dana Desa”, Jurnal Penelitian Politik, No. 2, Vol. 13, 2016.

Sutrisno Purwohadi Mulyono, "Sinergitas Penyelenggaraan Pemerintahan Desa", $M M H$, No. 3, Jilid 43, 2014.

Utang Suwaryo, “Mengembalikan Otonomi Untuk Desa”, Governance, No. 1, Vol. 2, 2011.

Yusnani Hasyimzoem, "Dinamikan Hukum Pemerintahan Desa", Fiat Justisia Jurnal Ilmu Hukum, No. 3, Vol. 8, 2014.

\section{Peraturan Perundang-undangan}

Undang-Undang Dasar 1945

Undang-Undang Nomor 6 Tahun 2014 Tentang Desa.

Peraturan Pemerintah Nomor 43 Tahun 2014 tentang peraturan pelaksana Undang - Undang Undang No. 6 tahun 2014 tentang Desa.

Peraturan Pemerintah Nomor 60 Tahun 2014 tentang Dana Desa yang Bersumber dari Anggaran Pendapatan dan Belanja Negara. 